\title{
New whitefly genus and species (Hemiptera, Aleyrodidae) breeding on Orophea katschallica Kurz in India
}

\author{
Anil Kumar DUBEY ${ }^{\circledR}$ \\ Zoological Survey of India, Andaman and Nicobar Regional Centre, Andaman and Nicobar Islands, \\ Port Blair, India 744102. \\ Corresponding author: anil.2kd@gmail.com \\ urn:1sid:zoobank.org:author:2C778EF7-19FB-464B-AF26-9D951E750E9C
}

\begin{abstract}
A new whitefly genus, Rudisculptus gen. nov. is described for its type species Rudisculptus caudalis gen. et sp. nov. feeding on Orophea katschallica Kurz (Annonaceae) from the Andaman Islands, India. Rudisculptus gen. nov. is similar to the New World genus, Aleuropleurocelus Drews \& Sampson, 1956 and an Old World genus, Tetralicia Harrison, 1917 in pupal morphology, but differs in having the first abdominal setae, thoracic tracheal pores, caudal furrow, differentiated cephalothorax in slide mounts, the lingula excluded beyond the vasiform orifice. The new genus also differs from an Old World genus, Regiominutus Dubey, 2021 in habitus, pattern of wax secretion, shape, size, cuticle colour, raised lateral margin, extension of segment sutures and the lingula reaching outside the margin of the vasiform orifice, and in having the thoracic tracheal folds. Orophea katschallica is recorded as a new host plant for the whiteflies. Images of puparial habitus and types, line drawings and scanning electron microscope (SEM) microphotographs are provided.
\end{abstract}

Keywords. Aleuropleurocelus, Andaman Islands, Regiominutus, Rudisculptus, Tetralicia.

Dubey A.K. 2021. New whitefly genus and species (Hemiptera, Aleyrodidae) breeding on Orophea katschallica Kurz in India. European Journal of Taxonomy 787: 1-16. https://doi.org/10.5852/ejt.2021.787.1609

\section{Introduction}

Whiteflies are phloem sap-sucking insects and they are mainly identified using the fourth nymphal stage called 'puparium'. Whiteflies show a clear geographical isolation at the subfamily level, and endemism to particular geographical regions at the genus level; however, a few genera are widespread or cosmopolitan (Dubey 2020). Currently, the family Aleyrodidae Chou, 1963 includes 1705 species belonging to 192 genera and devided across four subfamilies including one fossil Bernaeinae Shcherbakov, 2000 (Evans et al. in press). There are 469 species belonging to 71 genera known from India (Sundararaj et al. 2021). Here, the pupal morphology of a new whitefly, collected on an endemic plant, Orophea katschallica Kurz (Annonaceae) from the Andaman Islands, India is assessed with its congeners. Puparial morphological features of the new species differentiating it from related genera entail the erection of a new genus, Rudisculptus gen. nov. During the mounting, the two halves of cephalothorax easily get separated from the submargin, thus leaving a window for observing details of ventral characteristics. The caudal furrow 
also breaks in the middle from the point of folding ventrally thus forming a pseudo-caudal tracheal pore, while the actual caudal pore opening lies below the dorsal surface. Scanning electron microscope (SEM) images of the new species confirmed the presence of posterior marginal setae, a caudal pore, and the absence of the submarginal wax glands ventrally. The new genus and species are described with details of the collection locality, line drawings, images of habitus, type specimens and SEM microphotographs. Further, the pupal morphology of the genus Aleuropleurocelus Drews \& Sampson, 1956 was observed through SEM imaging of a species typical of the genus, Aleuropleurocelus ceanothi (Sampson, 1945). A single puparium of $A$. ceanothi donated by J.W. Dooley, USA, from the collections made by him in Hawaii, USA was examined for the wax secretion pattern on leaf surface/habitus and was used for SEM study, and the pupal morphology is clarified.

The type locality of the new taxa is the Table Delgarno Island in the Andaman and Nicobar Islands $\left(6^{\circ} 45^{\prime \prime}-13^{\circ} 41^{\prime \prime} \mathrm{N}, 92^{\circ} 12^{\prime \prime}-93^{\circ} 57^{\prime \prime} \mathrm{E}\right)$, which are located in the Indian ocean and isolated from mainland India by a sea distance of about $1600 \mathrm{~km}$. They remain in pristine condition and have been less explored for their organismal diversity (Dubey 2020); these islands constitute one of the biodiversity hotspot zones with adjoining countries under Sundaland, and need to be explored for their faunal resources (Dubey in press). So far, 30 whitefly species under 22 genera (including the new taxa described here)
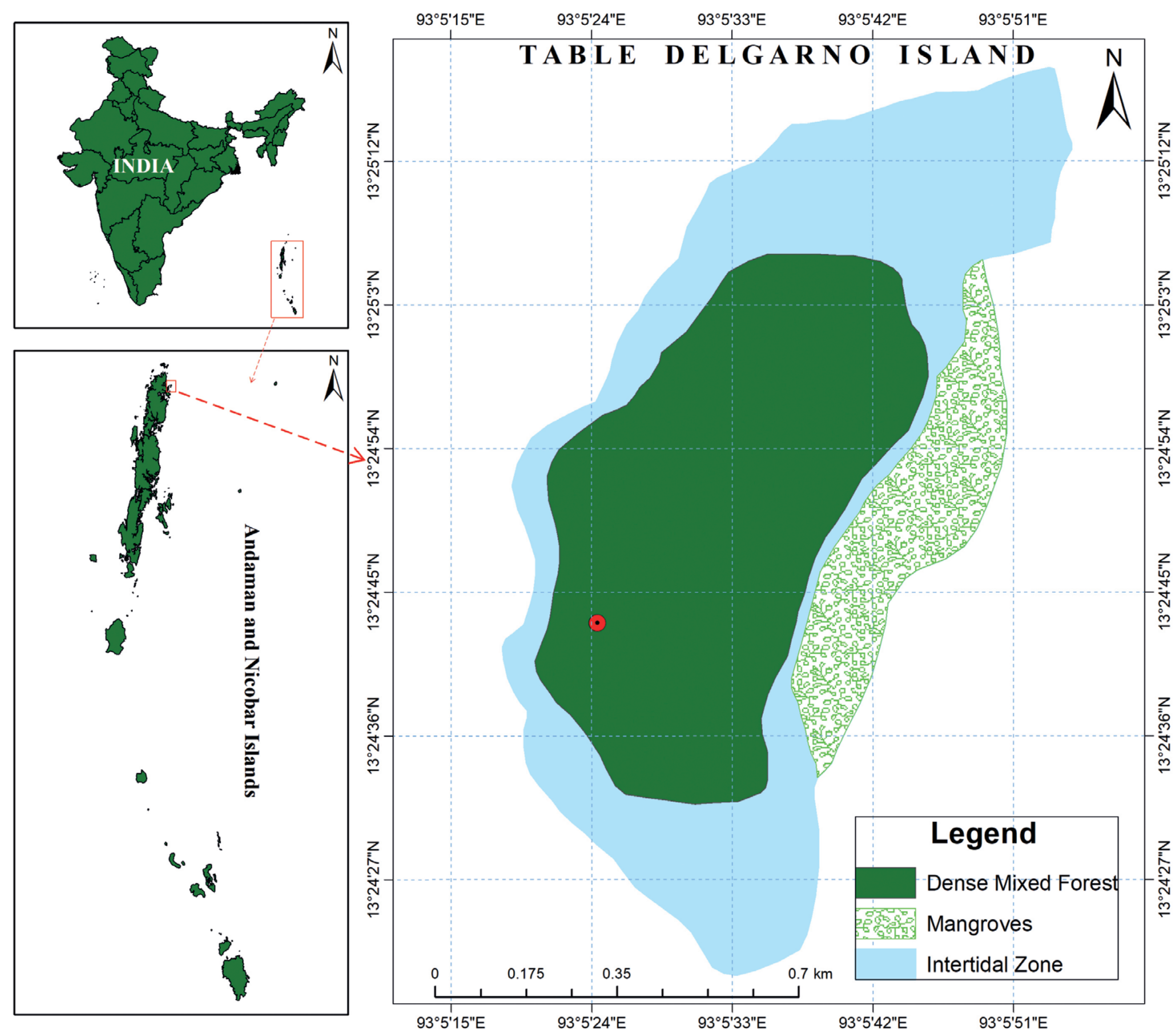

Fig. 1. Collection locality of the new taxa marked with red circle. 
have been reported from these islands. Orophea katschallica Kurz (Annonaceae) is an endemic plant of the Andaman and Nicobar Islands. This is the first record of a whitefly species from this host plant.

\section{Material and methods}

\section{Taxon sampling, sample preparation, and terminology}

Puparia of the new whitefly species were collected from the Table Delgarno Island located in the North Andaman Group of Islands, India. Further microscopic studies were carried out in the Andaman and Nicobar Regional Centre (ANRC), Zoological Survey of India (ZSI), Port Blair. Puparia were mounted following Dubey \& David (2012).

Morphological structure terminology follows Bink-Moenen (1983), Martin (1985) and Gill (1990). Type locality was mapped (Fig. 1) using ArcGIS, ArcMap ver. 10.4.1, ESRI India software.

\section{Institutional abbreviations}

Type series established in this study are deposited in the following collections.

ANRC-ZSI $=$ Andaman and Nicobar Regional Centre, Zoological Survey of India, Port Blair, India

NFIC-FRI = National Forest Insect Collection, Forest Research Institute, Dehradun, India

$\mathrm{NHM}=$ The Natural History Museum (NHM), London, United Kingdom

NZC $=$ National Zoological Collection, Kolkata, India

\section{Light microscopes and SEM study}

An M205 Leica microscope assembled with an auto-montage camera was used for imaging puparial habitus on the host leaf. A Labomed LX 400 compound microscope was used for identification. Both microscopes belonged to ANRC, ZSI, Port Blair. Images of type specimens were taken using an automontage camera attached to a Nikon made compound microscope Eclipse ver. 50i from the ANRC, Botanical Survey of India (BSI), Port Blair. Measurements were taken from six puparia.

SEM imagings (20 kV/EHT, $20 \mathrm{~Pa}, 24 \mathrm{~nm}$, Au-Pa alloy coat) were done using an EVO MA ver. 10 and MA 15 microscopes (Carl Zeiss, Jena, Germany) between $322 \times$ and 115,000 $\times$ magnification following sample preparation method as in Dubey \& Ramamurthy (2013). SEM imagings were done at Division of Entomology, Indian Agricultural Research Institute, New Delhi and Zoological Survey of India, Kolkata, India.

\section{Results}

Class Insecta Linnaeus, 1758

Order Hemiptera Linnaeus, 1758

Suborder Sternorrhyncha Amyot \& Serville, 1843

Infraorder Aleyrodomorpha Chou, 1963

Superfamily Aleyrodoidea Westwood, 1840

Family Aleyrodidae Westwood, 1840

Subfamily Aleyrodinae Westwood, 1840

Genus Rudisculptus Dubey gen. nov.

urn:1sid:zoobank.org:act:78F3AF0A-7736-4AB7-BDE5-8223B3DB36C9

\section{Type species}

Rudisculptus caudalis gen. et sp. nov.; by present designation and monotypy. Gender: masculine. 


\section{Diagnosis (Figs 2-6)}

In life, puparia black; without secretion of wax over dorsum, wax secretions are seen around caudal tracheal pore; elevated by lateral submargin; submargin merging with subdorsum by a ridge at dorsolateral angle; submargin hidden in dorsal aspect (Figs 2, 5B). Dorsal surface ornamented with reticulated network of tubercles. Submarginal bands of microtubercles present. Laterally elevated submargin expands and folds in mounted puparia and thus, placing the true margin ventrally. Thoracic tracheal pores indicated as small openings at true margin, and marked as deep loops on dorsal submargin, filled with fine microtubercles. Longitudinal moulting suture reaching margin and transverse moulting sutures reaching subdorsal-submarginal demarcation, cephalothorax separated from the submargin in mounted specimens (Fig. 4G); cephalothoracic and abdominal segment sutures reaching submedian area. Anterior marginal setae absent and posterior marginal setae located ventrally on true margin. Cephalic, first, eighth abdominal and caudal setae present, caudal setae located at ventrolateral margin. Vasiform orifice subcordate; operculum covering little more than half the length of the orifice; lingula exposed, tonguelike, tip may reach beyond the margin of the orifice. Caudal furrow prominent. Geminate pores present. Ventral submargin marked with a narrow groove except caudal fold area.

\section{Etymology}

The genus epithet is a summative of two Latin words 'rudis' and 'sculptus' meaning 'rough' and 'sculpted' attributing to the dorsal surface of puparium seen in the SEM images (Fig. 5B).

\section{Remarks}

Puparia of the new genus differ from those of Aleuropleurocelus and Tetralicia Harrison, 1917 in having a smooth true margin and the presence of first abdominal setae, with thoracic tracheal pores indicated at the margin, prominent caudal furrow, a differentiated cephalothorax in some slide mounts, the submargin is demarcated from the dorsal disc at the anterolateral angle by a shallow ridge, the subventral area is demarcated from the narrow submarginal area by a shallow groove, and the thoracic and caudal tracheal folds are not marked with spinules. In the new genus, the inner wall of the vasiform orifice has digitiform projections, the thoracic tracheal pores are clearly indicated at the margin with an extended loop on the submargin, filled with microtubercles and lacking submarginal wax secreting glands, but in Aleuropleurocelus, the inner wall of the vasiform orifice is smooth, the tracheal pore areas are not modified at the margin and the marginal teeth have wax glands at the base. The new genus also differs from Regiominutus Dubey, 2020 in the puparial shape, size, vasiform orifice structure, and in lacking submarginal papillae and a ventral submarginal groove. A comparison of pupal morphological characters with related genera are presented in Table 1.

Rudisculptus caudalis Dubey gen. et sp. nov. urn:lsid:zoobank.org:act:68BF5111-D73A-4C39-B082-80E305AE1FAF

Figs $2-6$

\section{Diagnosis}

Puparia of the new whitefly are characterised by the following combination of characters: smooth margin, elevated submargin, tuberculate/rugose dorsum, presence of first abdominal setae, demarcated cephalothorax, tracheal pores, caudal furrow, exposed lingula and lacking the submarginal wax glands.

\section{Etymology}

The species epithet is a Latin word 'caudalis' meaning 'caudal', attributing to the caudal furrow. 
Table 1. Comparison of puparial characters of Rudisculptus gen. nov. with related genera; updated from Dubey (2020).

\begin{tabular}{|c|c|c|c|c|}
\hline Characters & Rudisculptus gen. nov. & $\begin{array}{c}\text { Aleuropleurocelus } \\
\text { Drews \& Sampson, } 1956\end{array}$ & $\begin{array}{c}\text { Tetralicia } \\
\text { Harrison, } 1917 \\
\end{array}$ & $\begin{array}{c}\text { Regiominutus } \\
\text { Dubey, } 2021\end{array}$ \\
\hline color & black & black & black & white \\
\hline margin & smooth & irregularly teethed & smooth & smooth \\
\hline $\begin{array}{l}\text { cephalothorax } \\
\text { demarcation }\end{array}$ & differentiated & $\begin{array}{c}\text { not } \\
\text { differentiated }\end{array}$ & $\begin{array}{c}\text { not } \\
\text { differentiated }\end{array}$ & $\begin{array}{c}\text { not } \\
\text { differentiated }\end{array}$ \\
\hline first abdominal setae & present & absent & absent & present \\
\hline $\begin{array}{l}\text { separation of dorsal } \\
\text { submarginal by a } \\
\text { furrow/ridge }\end{array}$ & antero-lateral & absent & absent & present \\
\hline caudal furrow & present & absent & absent & present \\
\hline submargin & deflexed & deflexed & deflexed & deflexed \\
\hline $\begin{array}{l}\text { digitiform projections } \\
\text { in the orifice }\end{array}$ & present & absent & absent & present \\
\hline $\begin{array}{l}\text { lingula reaching } \\
\text { beyond the orifice }\end{array}$ & yes & no, obscured & no, obscured & $\begin{array}{l}\text { no, within the } \\
\text { orifice }\end{array}$ \\
\hline
\end{tabular}

\section{Type material}

\section{Holotype}

INDIA - +; puparium, on slide; Andaman and Nicobar Islands, North Andaman, Diglipur, Table Delgarno Island; $13^{\circ} 24.46 .88^{\prime}$ N, $93^{\circ} 05.18 .43^{\prime}$ E; alt. 9 m; 22 Oct. 2017; A.K. Dubey leg.; on Orophea katschallica; 14690 (1); ANRC-ZSI.

\section{Paratypes}

INDIA - 8 puparia on 6 slides; same collection data as for holotype; NZC -3 puparia on 1 slide; same collection data as for preceding; NFIC-FRI 11 puparium on 1 slide; same collection data as for preceding; NHM $\bullet 3$ puparia on three slides; same collection data as for preceding; 14690 (2-4); ANRCZSI.

\section{Description}

PUPARIUM. Black; oval; prominently elevated above from lateral margin (Fig. 5A); without secretion of wax over dorsal disc or margin, small amount of wax at tracheal pore opening areas present (Fig. 2); broadest at first abdominal segment region (Fig. 5B); 680-720 $\mu \mathrm{m}$ long, 580-610 $\mu \mathrm{m}$ wide, including folded submargin; found singly on underside of leaves; 1-2 puparia per leaf.

MARGIN. True margin merging with slightly smaller ventral surface and placed below folded submargin; smooth; thoracic tracheal pore opening areas marked as small pores; loop with microtubercles/granules on submargin prominent at each thoracic tracheal pore opening area (Figs 3C, 4D). Caudal tracheal pore opening cannot be stated with confidence in slide mounts as submargin folds ventrally and posterior end break in middle of caudal furrow, forming pseudo-caudal pore, but clearly visible in SEM image (Fig. 6G). Anterior marginal setae absent. Posterior marginal setae present on true margin, placed ventrally (Fig. 6G).

Dorsum. Entire dorsal surface ornamented with tuberculate cells except submedian area of abdominal segments. Dorsal surface slightly larger than ventral surface, merging with submargin at dorsolateral angle (Fig. 5A), and submargin is connecting with ventral surface through inwardly directed raised 
submargin (Fig. 6E); raised submargin 67-80 $\mu \mathrm{m}$ wide. Submargin expands outwards in slide mounts thus, loops on submargin, near thoracic tracheal pore, appear inversely oriented (inside-out) and pore opening area at true margin remains obscured (Fig. 4C), and their (pores/loops) orientations were confirmed through dissection of a few puparia (Fig. 4D). Submarginal ridges prominent. Caudal tracheal furrow present. Longitudinal moulting suture reaching margin. Transverse moulting sutures turning anteriorly and usually entirely separating two halves of cephalothorax (Fig. 4G) or terminating opposite to mesothorax on subdorsal area in a few puparia. Cephalothoracic and abdominal segment sutures

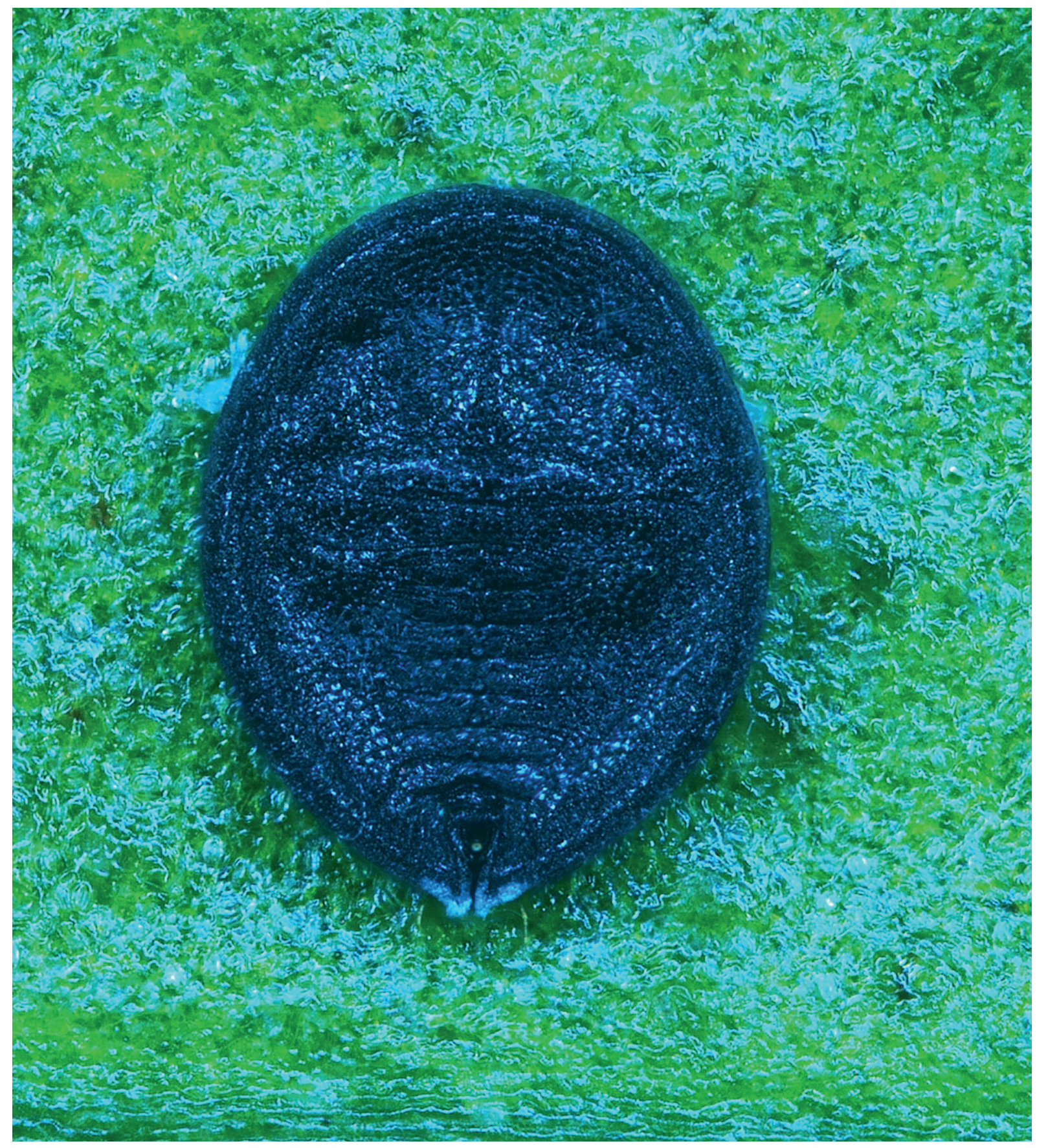

Fig. 2. Rudisculptus caudalis gen. et sp. nov., puparium, paratype (ANRC-ZSI), habitus on leaf. 
reaching subdorsum. Median length of cephalothorax and abdomen 345-355 and 345-360 $\mu \mathrm{m}$ long, respectively. Mesothorax 32-38 $\mu \mathrm{m}$ and metathorax 25-28 $\mu \mathrm{m}$ long, medially. Abdominal segment VII not reduced in middle length and almost equal to segment VI. Median length of abdominal segments VIVIII (A6-A8): A6: 25, A7: 17-20, A8: 30-35 $\mu \mathrm{m}$ long. Median tubercles present on abdominal segment I-VI. Submedian pockets and depressions may be recognized by spacing of microtubercles on segment sutures or inter-segmental spaces. Vasiform orifice inset from posterior apparent margin of pupal case by its own length. Caudal furrow present, 37-40 $\mu \mathrm{m}$ long excluding folded submargin, 50-80 $\mu \mathrm{m}$ long including folded submargin. Geminate pores present in four rows, two rows on submedian area and one row each on subdorsum and submargin; submarginal row of pores placed along true margin, more in number, 29-30 pairs (9-10 pairs on cephalothorax, 19-21 pairs on abdomen); submarginal row of geminate pores appear subdorsal in slide mounted puparia due to folding of submargin. Pore-porette spacing equal to or less than the diameter of large pore itself. Pockets continuous.

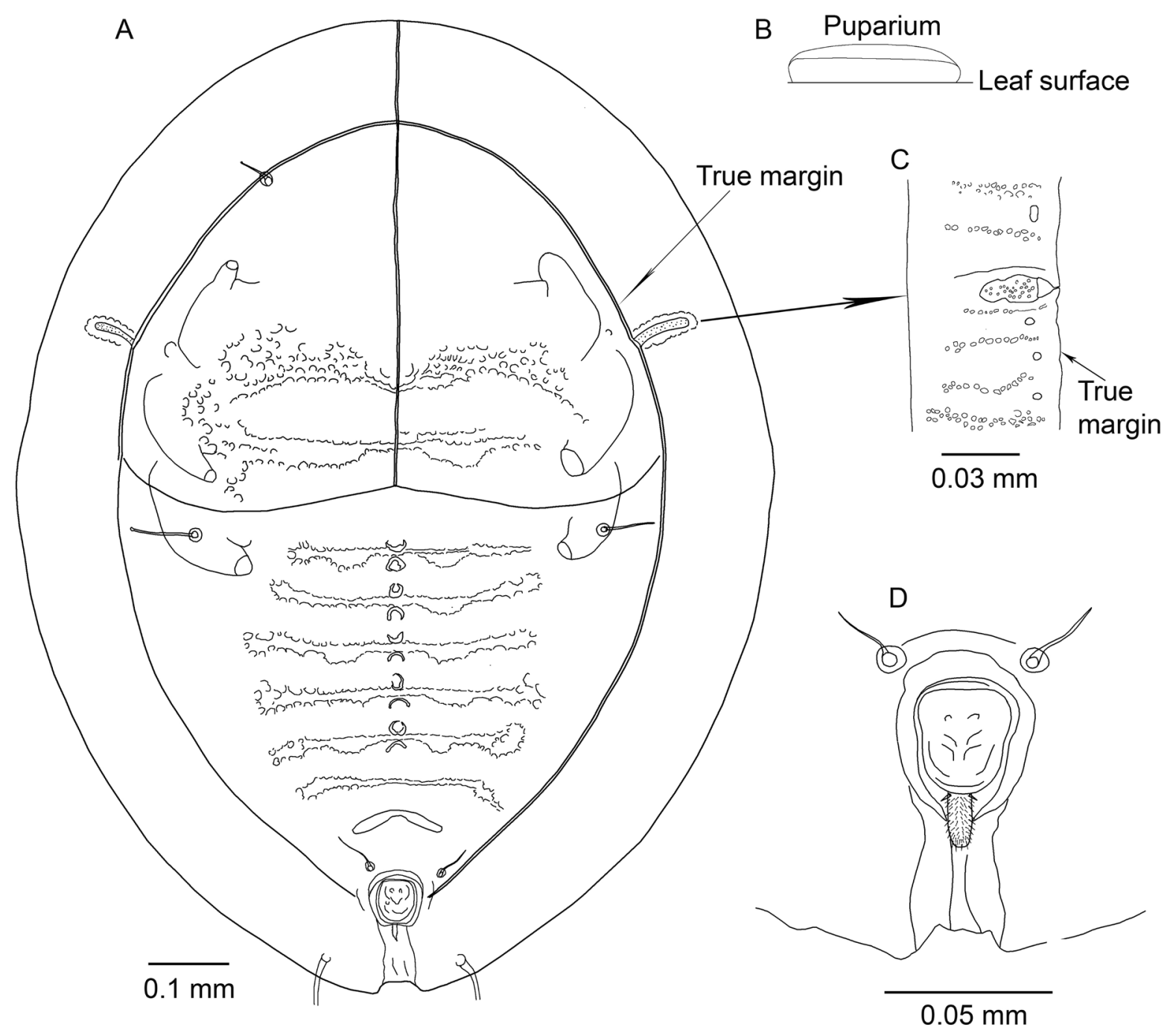

Fig. 3. Rudisculptus caudalis gen. et sp. nov.,, , holotype (ANRC-ZSI), line drawings. A. Dorsal and ventral views. B. Diagrammatic presentation of puparium on leaf in lateral view. C. Thoracic tracheal pore. D. Vasiform orifice. 


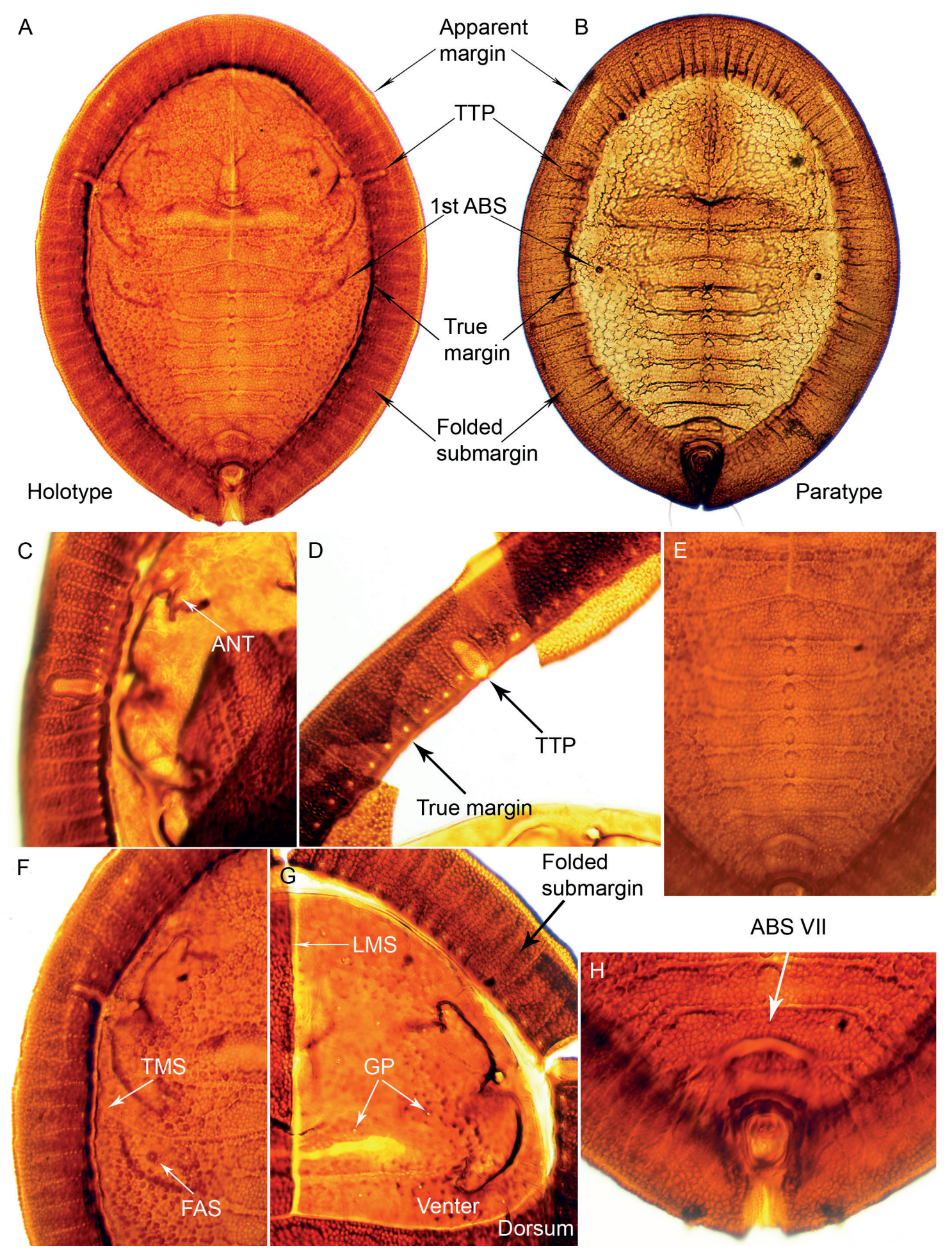

Fig. 4. Rudisculptus caudalis gen. et sp. nov., slide mounts. A. Puparium, , holotype (ANRC-ZSI). B. Puparium, paratypes (ANRC-ZSI). C. Thoracic tracheal pore (PT). D. True margin. Pore (PT). E. Abdominal segments (HT). F. Moulting suture; seta (HT). G. Cephalothoracic demarcation (PT). H. Posterior abdominal area (HT). Abbreviations: ABS VII = abdominal segment VII; ANT = antenna; FAS = first abdominal setae; GP = geminate pore; HT = holotype; LMS = longitudinal moulting suture; $\mathrm{PT}=$ paratype; $\mathrm{TMS}=$ transverse moulting suture; $\mathrm{TTP}=$ thoracic tracheal pore; $1 \mathrm{st} \mathrm{ABS}=$ first abdominal setae. 

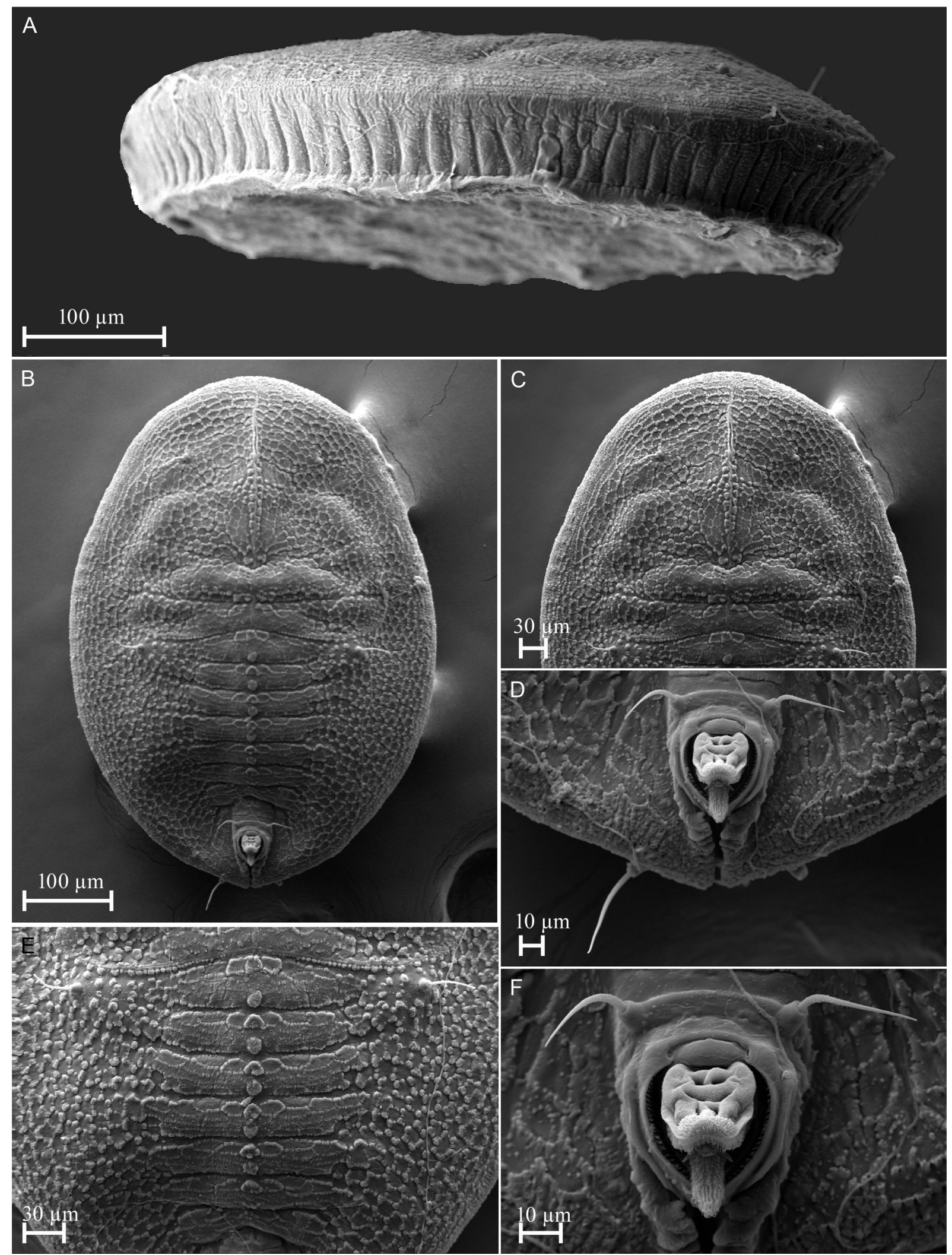

Fig. 5. Rudisculptus caudalis gen. et sp. nov., puparium, not preserved, SEM images. A. Ventrolateral view. B. Dorsal view. C. Cephalothorax. D. Posterior abdominal area. E. Abdominal segment. F. Vasiform orifice. 


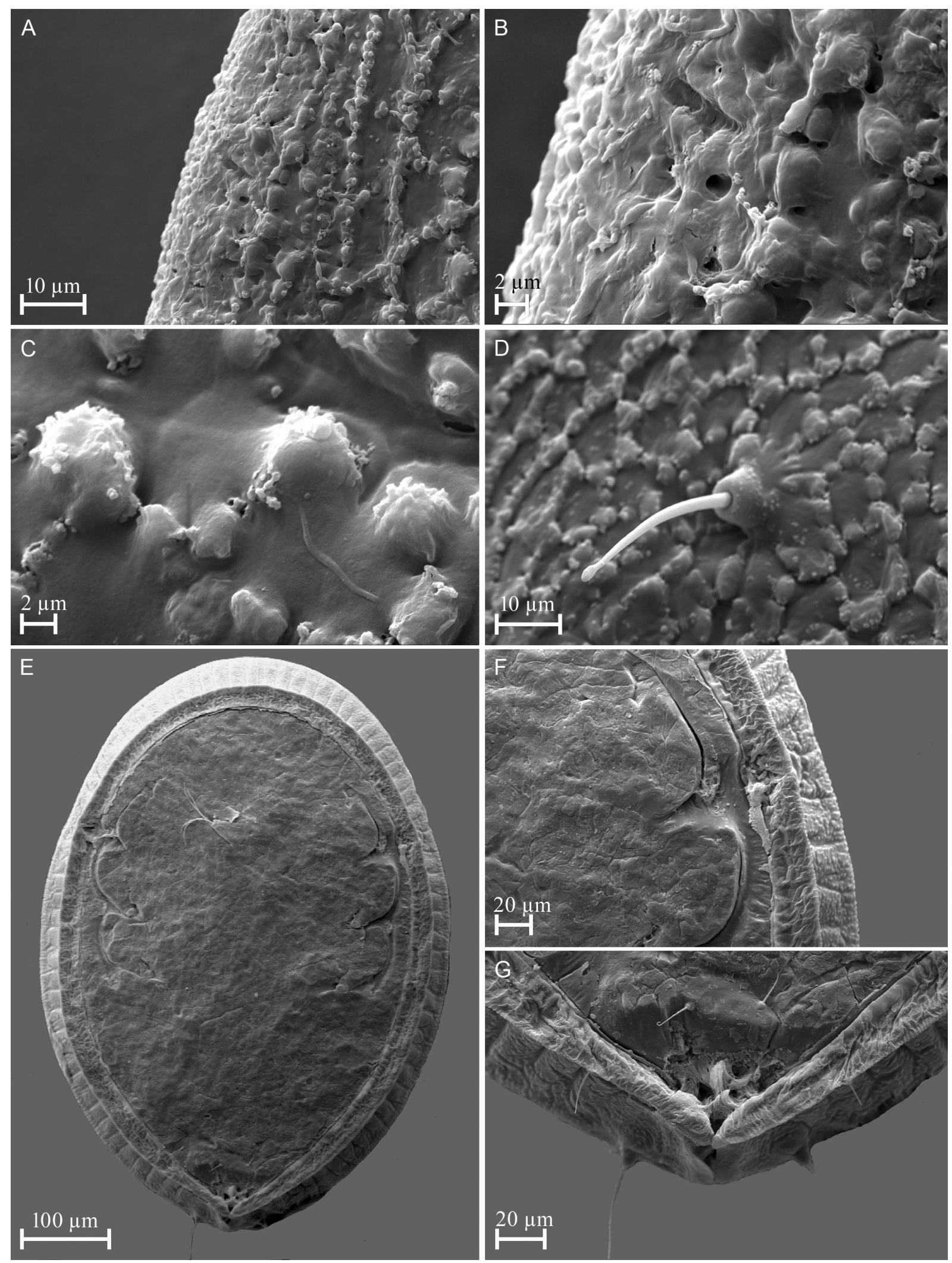

Fig. 6. Rudisculptus caudalis gen. et sp. nov., puparium, not preserved, SEM images, dorsal and ventral surfaces. A. Microtubercles, dorsal surface. B. Same, enlarged view. C. Geminate pore. D. Cephalic seta. E. Puparium, ventral surface. F. Thoracic tracheal fold. G. Caudal tracheal fold. 
VASIFORM OrIFICE. Subcordate; inner margin with row of many digitiform projections; $35-40 \mu \mathrm{m}$ long, 35-38 $\mu \mathrm{m}$ wide; operculum subcordate, dorsal surface with a few punctures, dorsal apical end with tuft of microtrichia and underside with many microtrichia, 22-28 $\mu \mathrm{m}$ long, 22-25 $\mu \mathrm{m}$ wide; almost entirely covering orifice. Lingula setose, exposed, elongate, tip reaching outside orifice, base with pair of thick setae (Figs 3D, 5F).

Venter. Smaller than dorsal surface. Prominent shallow submarginal groove/fold differentiating subventral area from ventral submargin. Thoracic tracheal folds present, without stipples (Fig. 6EF). Caudal tracheal fold present. Paired ventral eighth abdominal setae present (Fig. 6G). Antennae extending through inside prothoracic legs, reaching near base of prothoracic legs (Fig. 4C). Apical pads, adhesive sacs and spiracles visible.

Снаетотаху. Cephalic, first, eighth abdominal and caudal setae 22-28, 17-38, 20-28 and 38-65 $\mu \mathrm{m}$ long, respectively. Cephalic and first abdominal setae capitate (Fig. 6D). Caudal setae located on posterolateral submargin merging with dorsal surface.

\section{Host plant}

Annonaceae: Orophea katschallica Kurz.

\section{Distribution}

India: Andaman and Nicobar Islands, North Andaman.

\section{Remarks}

In life, puparia of the new species are seen without secretion of wax around the margin, except tracheal pore openings, but in A. ceanothi the wax threads originate from the true margin located ventrally
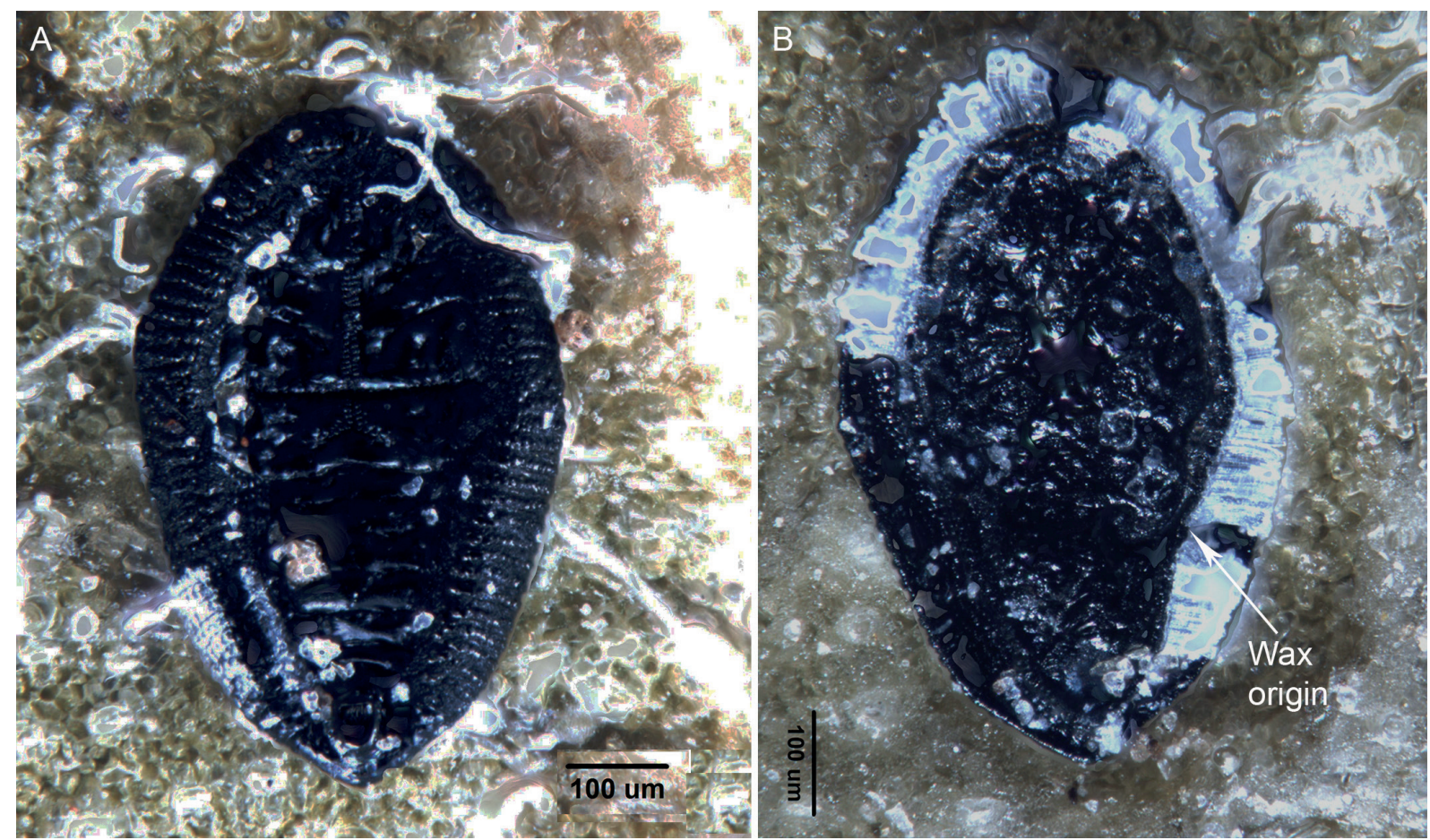

Fig. 7. Aleuropleurocelus ceanothi (Sampson, 1945), habitus. A. Dorsal view. B. Ventral view. 

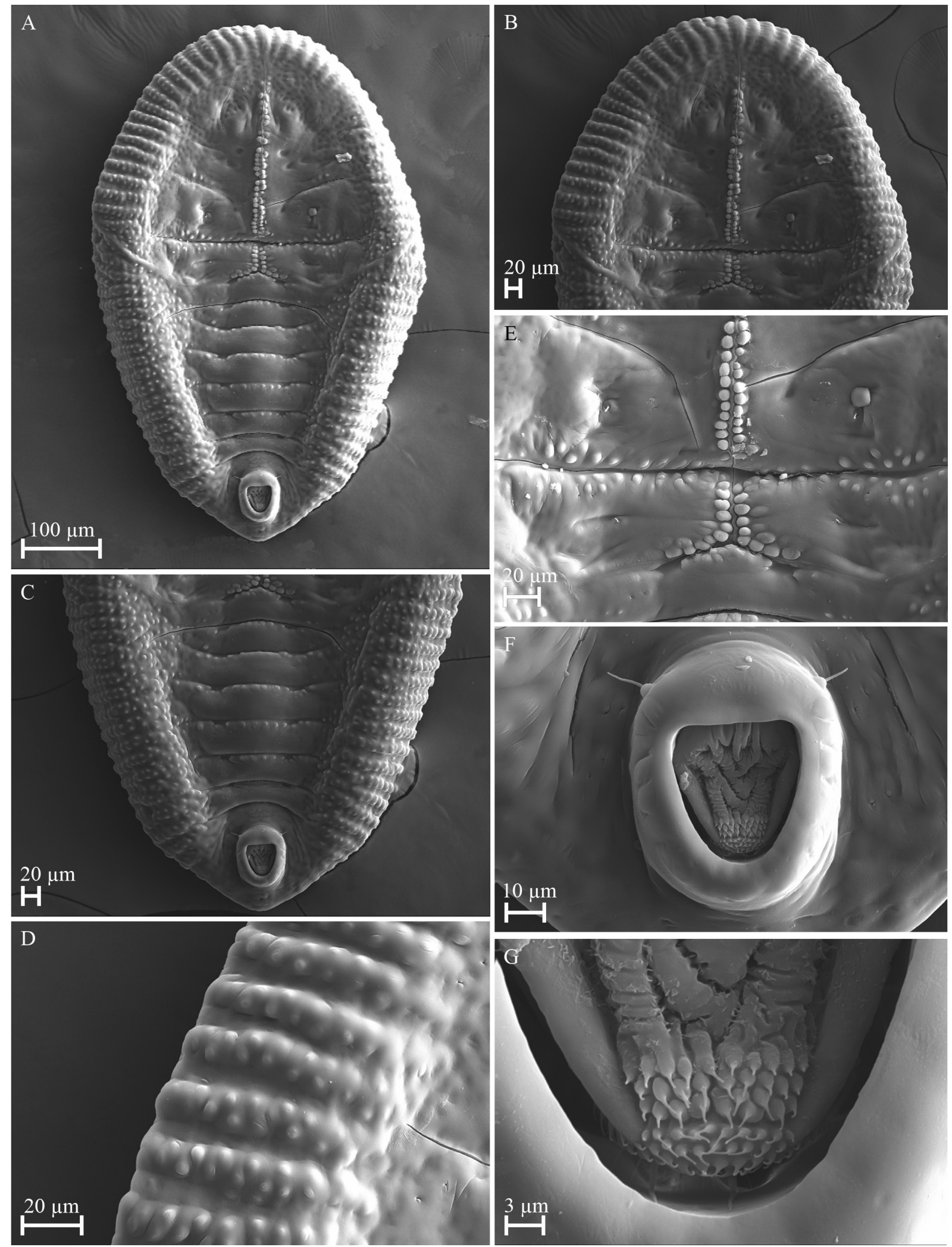

Fig. 8. Aleuropleurocelus ceanothi (Sampson, 1945), SEM microphotographs. A. Puparium, dorsal view. B. Cephalothorax. C. Abdominal area. D. Folded submargin. E. Meso- and metathorax, longitudinal suture. F. Vasiform orifice. G. Operculum apex, tuft of conical microtrichia. 


\section{DUBEY A.K., New whitefly genus and species from India}

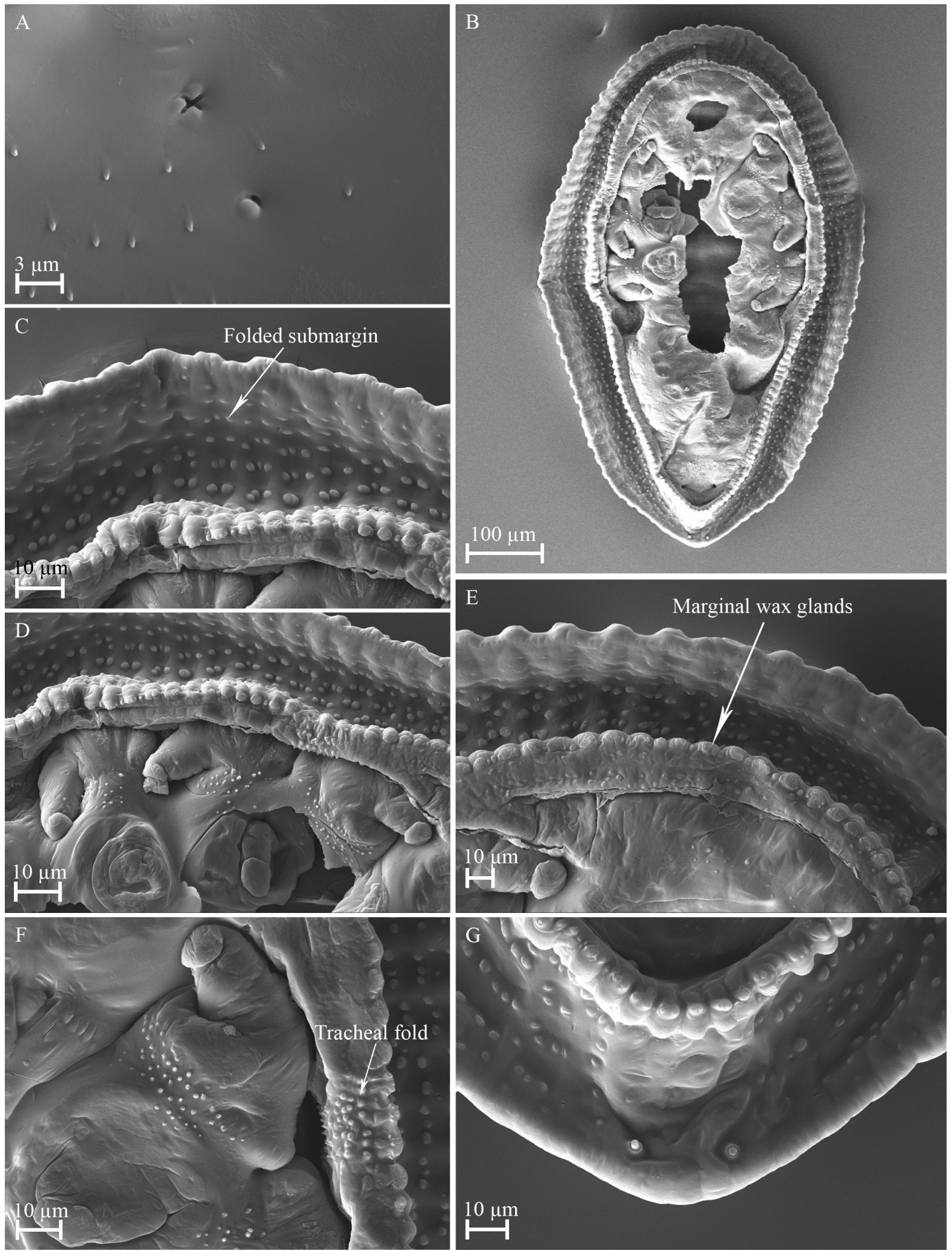

Fig. 9. Aleuropleurocelus ceanothi (Sampson, 1945), SEM microphotographs. B-G. Ventral views. A. Puparium, geminate pore. B. Ventral view. C. Ventrally folded submargin. D. Legs, stipples, spiracle. E. Marginal wax glands. F. Thoracic tracheal fold. G. Caudal tracheal pore and furrow area. 
(Fig. 7A-B). The ventral surface was smaller or equal to the dorsal surface, excluding the submargin. Populations of the puparia of the new taxa were very low on leaves, only one or two puparia were observed per leaf; puparia easily get detached from leaves in transport; hard in nature and break-down during mounting. The type locality of the new species, Table Delgarno Island, is a small island, prone to rain and heavy winds throughout the year, and this could be a reason for smaller populations of the new taxa. No whitefly adults and ants in attendance were observed in the field. The differences in morphological characters from related genera, geographical isolation of type locality and association with an endemic host plant indicate that the new genus may be native to and distributed in the Oriental Region only.

\section{Discussion}

The pupal morphology has been used for identification of whiteflies, and an examination of the ventral surface characteristics requires either a dissection or high-resolution imaging involving SEM. Here, puparia of the new species were dissected and SEM imagings were done for observing the surface morphology to differentiate it from the related genera, Aleuropleurocelus and Tetralicia. Tetralicia is more closely related to the New World genus Aleuropleurocelus and mainly distributed in the Old World, but not from the Oriental Region. These two genera have similar characteristics that resulted in transfer of a few species from Tetralicia to Aleuropleurocelus, including A. ceanothi. Martin (1999) provided a generic diagnosis for Tetralicia with a remark "If this character is of truly generic significance, then the two [Tetralicia and Aleuropleurocelus] may prove to be synonyms, because small numbers of species with this feature are found throughout the world". Based on the cladistic analysis carried out by Manzari \& Quicke (2006), this character seems to be far less reliable than has been assumed. Aleuropleurocelus is recognized by the following combination of characters: elongate or circular elliptical puparia, smaller venter, deflexed dorsum, ventrally located crenulate margin, vasiform orifice internally smooth, lingula hidden and first abdominal setae always absent (Martin 2005; Sánchez-Flores et al. 2020). An examination of the habitus on a leaf (Fig. 7A-B) and SEM studies on A. ceanothi confirmed that the submargin is not demarcated from the subdorsum (Fig. 8A-C), the subdorsal/submarginal area rises dorsally (Fig. 8D), expands and folds ventrally (Fig. 9B-C), and then merges with the ventral surface (Fig. 9D); the anterior dorsal end of the operculum bears papillae-form microtrichia (Fig. 8F-G); geminate pores are present (Fig. 9A); the tracheal pore opening areas are not modified in the margin; the ventral surface is distinctly smaller than the dorsal surface, without submarginal groove/fold or thoracic tracheal folds, and the bases of legs have papillae-form spinules (Fig. 9F). The SEM study also confirmed that the true margin in Aleuropleurocelus is irregularly toothed, each tooth bearing a wax secreting gland at the base (Fig. 9E) and the location of the origin of wax threads from the margin is below the puparium (Fig. 7B); this supports Aleuropleurocelus and Tetralicia as distinct genera. It is clarified here that Aleuropleurocelus fundamentally differs from Rudisculptus gen. nov. and Tetralicia in having marginal wax glands; and Rudisculptus differs from Aleuropleurocelus and Tetralicia in having tracheal pores, presence of a first abdominal setae and a caudal furrow.

\section{Acknowledgments}

Thanks are due to the Director, ZSI, Kolkata, Officer in-Charge, ANRC/ZSI, and L.J. Singh, Head of Office, ANRC/BSI, Port Blair for microscopic facilities. Vivek Kumar, ANRC/BSI, is thankfully acknowledged for identification of the host plants. The Ministry of Environment, Forests and Climate Change, Govt. of India, New Delhi is greatly acknowledged for financial assistance.

\section{References}

Amyot C.J.-B. \& Audinet-Serville J.G. 1843. Deuxième partie. Homoptères. Homoptera Latr. Histoire naturelle des Insectes. Hemiptères 1843. Librairie encyclopédique de Roret, Paris. 
Bink-Moenen R.M. 1983. Revision of the African whiteflies (Aleyrodidae), mainly based on a collection from Tchad. Monografieën Nederlandse Entomologische Vereniging 10: 1-210.

Chou I. 1963. Some viewpoints about insect taxonomy. Acta Entomologica Sinica 12: 586-596.

Drews E.A. \& Sampson W.W. 1956. Tetralicia and a new related genus, Aleuropleurocelus. Annals of the Entomological Society of America 49: 280-283. https://doi.org/10.1093/aesa/49.3.280

Dubey A.K. 2020. Regiominutus ventralis gen. et sp. nov. (Hemiptera: Aleyrodidae) infesting Aglaia elaeagnoides (Meliaceae) on the Andaman archipelago, India. Entomological Science 23: 1-11. https://doi.org/10.1111/ens.12458

Dubey A.K. in press. Description of a new whitefly (Hemiptera: Aleyrodidae) breeding on Strychnos wallichiana Steud. ex A. DC. (Gentianales: Loganiaceae) in the Andaman Islands, India. Pan-Pacific Entomologist 97 (4): in press.

Dubey A.K. \& David B.V. 2012. Collection, preservation and preparation of specimens for taxonomic study of whiteflies (Hemiptera: Aleyrodidae). In: David B.V. (ed.) The Whiteflies or Mealywing Bugs: Biology, Host Specificity and Management: 1-19. Lambert Academic Publishing, Germany.

Dubey A.K. \& Ramamurthy V.V. 2013. Dialeurolonga re-defined (Hemiptera: Aleyrodidae): with a new genus and species from India, two new genera from Australia, and discussion of host-correlated puparial variation. Zootaxa 3616: 548-562. https://doi.org/10.11646/zootaxa.3616.6.2

Evans G.A., Martin J.H., Drohojowska J., Stocks I.C., Dooley J., Dubey A.K. \& Szwedo J. in press. Whiteflies of the World (Hemiptera: Sternorrhyncha, Aleyrodidae) - a catalogue of the taxonomy, distribution, hosts and natural enemies of whiteflies. Part 1 - Subfamilies Aleurodicinae, Udamoselinae, Bernaeinae and other fossil whiteflies. Zootaxa: in press.

Gill R.J. 1990. The morphology of whiteflies. In: Gerling D. (ed.) Whiteflies: their Bionomics, Pest Status and Management: 13-46. Intercept, Andover.

Harrison J.W.H. 1917. A new species and genus of Aleyrodidae from Durham. The Vasculum 3: 60-62.

Linnaeus C. 1758. Systema naturae per regna tria naturae, secundum classes, ordines, genera, species, cum characteribus, differentiis, synonymis, locis. Tomus I. Editio decima, reformata. Laurentii Salvii, Holmiæ. https://doi.org/10.5962/bhl.title.542

Martin J.H. 1985. The whitefly of New Guinea (Homoptera: Aleyrodidae). Bulletin of the British Museum (Natural History), Entomology 50: 303-351.

Martin J.H. 2005. Whiteflies of Belize (Hemiptera: Aleyrodidae). Part 2 - review of the subfamily Aleyrodinae Westwood. Zootaxa 1098: 1-116. https://doi.org/10.11646/zootaxa.1098.1.1

Martin J.H. 1999. The whitefly fauna of Australia (Sternorrhyncha: Aleyrodidae), a taxonomic account and identification guide. Technical Paper, CSIRO Entomology 38: 1-197.

Manzari S. \& Quicke D.L.J. 2006. A cladistic analysis of whiteflies, subfamily Aleyrodinae (Hemiptera: Sternorrhyncha: Aleyrodidae). Journal of Natural History 40: 2423-2554.

https://doi.org/10.1080/00222930601121890

Sampson W.W. 1945. Five new species of Aleyrodidae from California (Homoptera). Pan-Pacific Entomologist 21: 58-62.

Sánchez-Flores O.A., Carapia-Ruiz V.E., Coronado-Blanco J.M. \& Ruiz-Cancino E. 2020. Description of Aleuropleurocelus sampsoni sp. nov. (Hemiptera: Aleyrodidae) from Tamaulipas, Mexico. Florida Entomologist 103 (2): 274-280. https://doi.org/10.1653/024.103.0219 
Shcherbakov D.E. 2000. The most primitive whiteflies (Hemiptera; Aleyrodidae; Bernaeinae subfam. nov.) from the Mesozoic of Asia and Burmese amber, with an overview of Burmese amber hemipterans. Bulletin of the Natural History Museum London (Geology) 56: 29-37.

Sundararaj R., Krishnan S. \& Sumalatha B.V. 2021 Invasion and expansion of exotic whiteflies (Hemiptera: Aleyrodidae) in India and their economic importance. Phytoparasitica (available online). https://doi.org/10.1007/s12600-021-00919-7

Westwood J.O. 1840. An Introduction to the Modern Classification of Insects Founded on the Natural Habits and Corresponding Organization of Different Families. Longman, Orme, Brown and Green, London. https://doi.org/10.5962/bhl.title.12455

Manuscript received: 11 August 2021

Manuscript accepted: 8 November 2021

Published on: 27 December 2021

Topic editor: Tony Robillard

Section editor: Christopher H. Dietrich

Desk editor: Eva-Maria Levermann

Printed versions of all papers are also deposited in the libraries of the institutes that are members of the EJT consortium: Muséum national d'histoire naturelle, Paris, France; Meise Botanic Garden, Belgium; Royal Museum for Central Africa, Tervuren, Belgium; Royal Belgian Institute of Natural Sciences, Brussels, Belgium; Natural History Museum of Denmark, Copenhagen, Denmark; Naturalis Biodiversity Center, Leiden, the Netherlands; Museo Nacional de Ciencias Naturales-CSIC, Madrid, Spain; Real Jardín Botánico de Madrid CSIC, Spain; Zoological Research Museum Alexander Koenig, Bonn, Germany; National Museum, Prague, Czech Republic. 